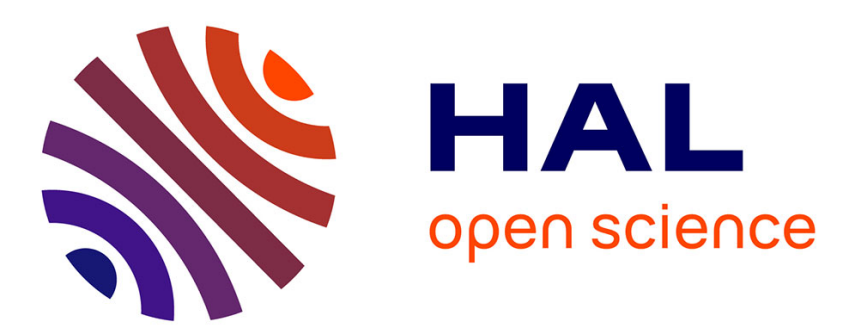

\title{
Who's winning the low-carbon innovation race? An assessment of countries' leadership in renewable energy technologies
}

Clément Bonnet, Emmanuel Hache, Gondia Sokhna Seck, Marine Simoen, Samuel Carcanague

\section{To cite this version:}

Clément Bonnet, Emmanuel Hache, Gondia Sokhna Seck, Marine Simoen, Samuel Carcanague. Who's winning the low-carbon innovation race? An assessment of countries' leadership in renewable energy technologies. International Economics, 2019, 160, pp.31-42. 10.1016/j.inteco.2019.07.006 . hal02417569

\section{HAL Id: hal-02417569 \\ https://hal-ifp.archives-ouvertes.fr/hal-02417569}

Submitted on 19 Dec 2019

HAL is a multi-disciplinary open access archive for the deposit and dissemination of scientific research documents, whether they are published or not. The documents may come from teaching and research institutions in France or abroad, or from public or private research centers.
L'archive ouverte pluridisciplinaire HAL, est destinée au dépôt et à la diffusion de documents scientifiques de niveau recherche, publiés ou non, émanant des établissements d'enseignement et de recherche français ou étrangers, des laboratoires publics ou privés. 


\section{Who's winning the low-carbon innovation race? An assessment of countries' leadership in renewable energy technologies is}

Clément Bonnet $^{\mathrm{a}, \mathrm{c}^{*}}$, Emmanuel Hache ${ }^{\mathrm{a}, \mathrm{b}, \mathrm{c}}$ Gondia Sokhna Seck ${ }^{\mathrm{a}}$, Marine Simoën ${ }^{\mathrm{a}}$, Samuel Carcanague $^{\mathrm{b}}$

18 July 2019

Abstract:

Intellectual property is a central issue in climate negotiations. On the one hand, it shapes and encourages innovation in low-carbon technologies. On the other hand, it can reduce access to these technologies by giving patent holders market power. We analyse the interactions between climate negotiations and the acquisition of renewable energy technology patents. First, we present the history of climate negotiations, emphasizing the role of technologies. Second, we conduct an empirical analysis aimed at determining which countries could be considered leaders in renewable energy technologies (RETs). Major changes were observed in the geographical distribution of low-carbon innovation during the 2000s, foreshadowing a reorganization of the geopolitical balances of innovation in renewable energies.

Keywords: Patent data, energy transition, renewable energy technology, innovation, international relations.

JEL Classification: Q42, Q55, O31, O38.

\footnotetext{
This study received the financial support of the French National Research Agency (ANR) and this article is part of the GENERATE (Renewable Energies Geopolitics and Future Studies on Energy Transition) project. The authors are very grateful to François Kalaydjian and Jérôme Sabathier for their insightful comments and
} 
suggestions. Any remaining errors are of course ours. The views expressed herein are strictly those of the authors and are not to be construed as representing those of IFP Énergies Nouvelles.

a. IFP Énergies Nouvelles, 1-4 av. de Bois Préau, F-92852 Rueil-Malmaison, France.

b. French Institute for International and Strategic Affairs (IRIS), France.

c. EconomiX-CNRS, University of Paris Nanterre, France.

* Corresponding author. Tel.: +336454422 38

E-mail address: clement.bonnet@ifpen.fr 


\section{Introduction}

The consequences of global warming will affect all countries (Stern et al., 2006). And because atmospheric temperature has the characteristics of a public good, its protection requires countries to commit to reducing their greenhouse gas (GHG) emissions. This way of thinking about climate change is well known and places international climate negotiations, conducted within the UNFCCC ${ }^{1}$ framework, at the core of all hopes in the fight against climate change. However, the willingness shown by most States to make each session of the Conference of the Parties (COP) a success can partially conceal the geopolitical mechanisms that drive these negotiations. After the failure of COP15 in Copenhagen in 2009, US President Obama welcomed a significant agreement, "one that takes us farther than we have ever gone before as an international community", and welcomed the fact that the United States had renewed its leadership in the international climate negotiations. ${ }^{2}$ More recently, COP21 was almost unanimously hailed as a success by both governments and most media (Bodansky, 2016).

However, facts are stubborn and significant doubts remain as to the achievement of the objectives of the Paris Agreement. The nationally determined contributions (NDCs) pledged by States at COP21 would lead to an average global warming of between $2.6^{\circ} \mathrm{C}$ and $3.1^{\circ} \mathrm{C}$ above pre-industrial levels (Rogelj et al., 2016). Moreover, their revision following ratification of the agreement by a significant proportion of the countries concerned would likely limit global warming below $3.5^{\circ} \mathrm{C}{ }^{3}$ Three major risks undermine efforts to achieve the COP21 objectives (Peters et al., 2017): the low level of emission reduction commitments made so far, the low deployment rate of low-carbon technologies, and the centrality of socalled negative emission technologies, which are crucial in most scenarios but remain largely

\footnotetext{
${ }^{1}$ United Nations Framework Convention on Climate Change

${ }^{2}$ To put these remarks into perspective, the President was greeted on his arrival on the last day of the negotiations by Hillary Clinton with the words "Mr. President, this is the worst meeting I've been to since the eight-grade student council" (Meilstrup, 2010).

${ }^{3} \mathrm{https}: / /$ climateactiontracker.org/global/temperatures/
} 
hypothetical to date. ${ }^{4}$ It is also worth mentioning the non-linearity of GHG emission reduction costs which considerably increases financing needs after 2030, yet the commitments made at COP21 do not go beyond that date (Rose et al., 2017).

In many cases, these risks are related to low-carbon technology and diffusing it extensively. As such, limited diffusion of low-carbon technology may contribute to considerably increasing global warming mitigation costs (Iyer et al., 2015). This is not surprising since the energy transition to combat global warming can be described as a technological revolution (Criekemans, 2018). Understanding the gap between the objectives of the international community and the concrete actions of governments, means understanding the geopolitical issues related to low-carbon technologies and how they can influence the evolution of climate negotiations. In this article, we will focus more particularly on renewable energy technologies (RETs) because they are both central to policies to reduce energy production-related GHG emissions and perceived as very innovative sectors.

Low-carbon technologies are the subject of intense geo-economic competition between States. In many sectors, innovation and its protection are proving essential for the sustainability of economic growth, security and national sovereignty more generally. In the case of renewable energy sources, China's emergence and Western fears of losing a technological advantage have revived protection against foreign investment, which has increased in recent years. Germany, for example, changed its system in July 2017 after several takeovers of companies in sensitive sectors by foreign investors, including a wind energy company, WindMW GmbH, which came under Chinese control in 2016. The United States, the United Kingdom and China, for their part, amended their legislation to this effect in 2018, and France adapted its legislation under the PACTE Act. Although the energy sector in general is subject to

\footnotetext{
${ }^{4}$ On this point, simulation exercises show that if these technologies cannot be deployed on a large scale, shortterm actions must be significantly more ambitious than those announced so far (Larkin et al., 2018). Some authors speak of a bet made on the future, given the great uncertainties around negative-emitting technologies (Fuss et al., 2014).
} 
protection measures, more explicit inclusion of low-carbon technologies is being considered in the areas subject to foreign investment protections, particularly in France, with a variety of measures to put in place (total ban, control, etc.). Intellectual property is a field in which geoeconomic power can be exercised and the low-carbon nature of an innovation adds a level of complexity to this analysis by linking intellectual property to climate negotiations.

This geo-economic competition has had a crucial influence on international climate negotiations. In this respect, this article synthesizes and complements two corpus of literature on the role of technology in international climate negotiations. First, several studies conduct geographical, legal and geopolitical analyses to assess the extent to which industrial property may have been a blocking factor in international climate negotiations, and question its real impact on technology transfer. Thus, Barton (2007) conducted an early study comparing the impact of industrial property rules on the international technology transfer of PV solar, wind and biomass technologies. The study concluded that no results can be generalized to all technologies. Several other studies showed how Western and Southern countries have opposed each other on the issue of industrial property in the context of climate negotiations (Correa, 2013; Chuffart-Finsterwald, 2014; Abdel-Latif, 2015; Shabalala, 2016). Ockwell et al. (2010) analyzed the two conflicting discourses developed by the two groups of countries on industrial property. While developed countries argue that strong IP regimes are necessary for technology transfer as they guarantee that firms will not be imitated by their competitors, developing countries highlights how patents can prohibit access to new technologies by allowing firms to raise their prices. Their article highlights the oversimplification of both visions and these results suggest that countries might adopt a strategy that combines, in the context of international negotiations, a position that may differ from their national low-carbon technology strategy. Second, there are several empirical studies on the transfer of low-carbon 
technologies. Dechezleprêtre et al. (2013) evaluated the factors that explain why inventors in one country patent their inventions in foreign countries. They concluded that inventors are more reluctant to protect their inventions: (i) in countries where industrial property rules are too lax, (ii) in countries where the knowledge accumulated in the same technology is stronger. These results underlined the strategic nature of patent filings in foreign countries. In a relatively similar but more comprehensive study in terms of data, Dussaux et al. (2018) demonstrated that a strict industrial property regime will not have the same impacts on technology transfer depending on whether or not a country is part of the OECD. A study by Verdolini and Bosetti (2017) provided additional insights. The authors showed that climate policies implemented by a country may or may not attract patent applications from foreign inventors depending on the policy instrument. The non-market nature of their instruments would explain the low capacity of non-OECD countries to attract technology transfers. It pinpointed that the relations between climate negotiations, patent systems and technology transfer are difficult to apprehend and hard to generalize to all countries and technologies.

In this context, this paper aims to question the existence of technological leadership in renewable energy technologies based on a study of patents registered in the PATSTAT database between 1992 and 2014. We are particularly interested in the evolution of these strategies over time along three time periods that delimit the main stages of the international climate negotiations. The elements that differentiate these three time periods are, on the one hand, the intensity of low-carbon innovation and, on the other hand, the weights of the different countries in this global innovation dynamic; assessed with patent data. The analysis of international negotiations on low-carbon technology highlights three major dimensions in the geo-economics of low-carbon innovation: the efforts made by a country to specialize in a technology, the results of these efforts in terms of performance, and the penetration of foreign markets through the obtaining by a country's inventors of patents granted by foreign industrial 
property offices. The contribution of our paper is to empirically assess these three dimensions by taking into account changes in the innovation regime.

We are making a new contribution to the literature using patent data from the PATSTAT database (2018 autumn edition). The detailed information of this database allows us to produce indexes that accurately answer the questions raised by our analysis. To our knowledge, this is the first article that presents and analyses the temporal evolution of specialization indexes in solar PV and wind energy technologies for such a large sample of countries. The measurement of countries' innovation performance using the index presented in the subsection IV.i. is a novelty in the economic literature on innovation. Finally, the analysis of patent filing strategies abroad requires hard-to-access data and we are not aware of any study producing the empirical facts that we present and discuss.

The article is structured as follows. Section II highlights the importance of low-carbon innovation in climate negotiations and presents an overview of low-carbon technology dynamics during three periods that delimit three different stages of international negotiations. Section III examines the specialization dynamics of countries in two central technologies of the energy transition: wind and solar energy. Section IV assesses countries' innovation performance in RETs and the geographical scope of the protection over RETs, and section V concludes the paper.

\section{The importance of low-carbon innovation in climate negotiations}

\section{Data presentation and overview of low-carbon innovation dynamics}


The analysis we develop in this article relies on patent data extracted from the PATSTAT database. It contains more than 100 million patent documents from both industrialized and developing countries. Our analysis will focus in particular on patents protecting inventions in RETs. As such, we consider patents classified according to the Cooperative Patent Classification (CPC) scheme in the following technologies: wind power (onshore and offshore), solar photovoltaic, bio-fuels, fuel from waste, geothermal, solar thermal and hydropower. Regarding the latter category, we consider only inventions related to the use of marine energy and small hydropower installations, and exclude patents filed in hydropower dam technologies.

We consider patents granted between 1992 and 2014. The last year of our sample is 2014, because this is the last full year in the autumn 2018 edition of the PATSTAT database from which our dataset was extracted. ${ }^{5}$ Moreover, depending on the research question, both inventions and patents can be analysed; in this article the two variables are used. The distinction is that several patents can protect the same invention. Indeed, an agent seeking to patent an invention can choose to protect it in several geographical areas and will potentially obtain a patent for each. It is also possible to limit the scope to the invention itself. For that purpose, only the so-called priority filing patent of the invention, which is the first granted patent that has protected the invention in question, may be taken into account.

Finally, a central issue in analysis of patent data is determining the nationality of the inventions. In the next subsection, we will focus on RET patent filings in the main patent offices, regardless of the nationality of the applicant. In the rest of the article, inventions will be classified according their nationality. We consider that the nationality of an invention is

\footnotetext{
${ }^{5}$ https://forums.epo.org/latest-full-year-in-patstat-7117
} 
that of the residential address of the inventor registered at the time of priority filing, used for correspondence with the patent office. When the information is not available in the PATSTAT database, we consider that the invention is of the nationality of the Office in which it is protected for the first time. Indeed, there is a strong domestic bias among inventors in the sense that they will generally prefer to file the first patent on their invention directly within their country of residence, before considering extending the protection to other countries. ${ }^{6}$

As discussed in the introduction of this article, innovation in RETs has become a global focus in recent decades. No geographical area seems to have escaped the acceleration of intellectual property rights acquisition for new inventions in RET sectors, reflecting the expectation that these technologies are or will become key assets. Analysis of patents granted by the world's five largest intellectual property offices, namely the United States Patent and Trademark Office (USPTO) in the US, the European Patent Office (EPO), the State Intellectual Property Office (SIPO) in China, the Japan Patent Office (JPO) and the Korean Intellectual Property Office (KIPO) in South Korea, can be used to monitor global trends. Figure 1 shows the evolution of the share of RET patents among all patents granted by these five offices. Patents are not classified by year of granting, rather by year of application filing with the Office. ${ }^{7}$

Figure 1: Evolution of the share of RET patents in total patents granted by the five main intellectual property offices, and the three negotiations stages on climate technologies

\footnotetext{
${ }^{6}$ To illustrate this domestic bias, we have extracted all the priority patents filed between 1980 and 2014 for which the inventor's country of residence is known. In $91 \%$ of cases it corresponds to the country of the office that granted the priority patent.

${ }^{7}$ Classifying inventions according to the year in which the application was filed helps better reflect the temporality of innovators' decisions. The duration of the examination of applications is likely to vary from one office to another and a classification by year of patent grant could bias the results.
} 


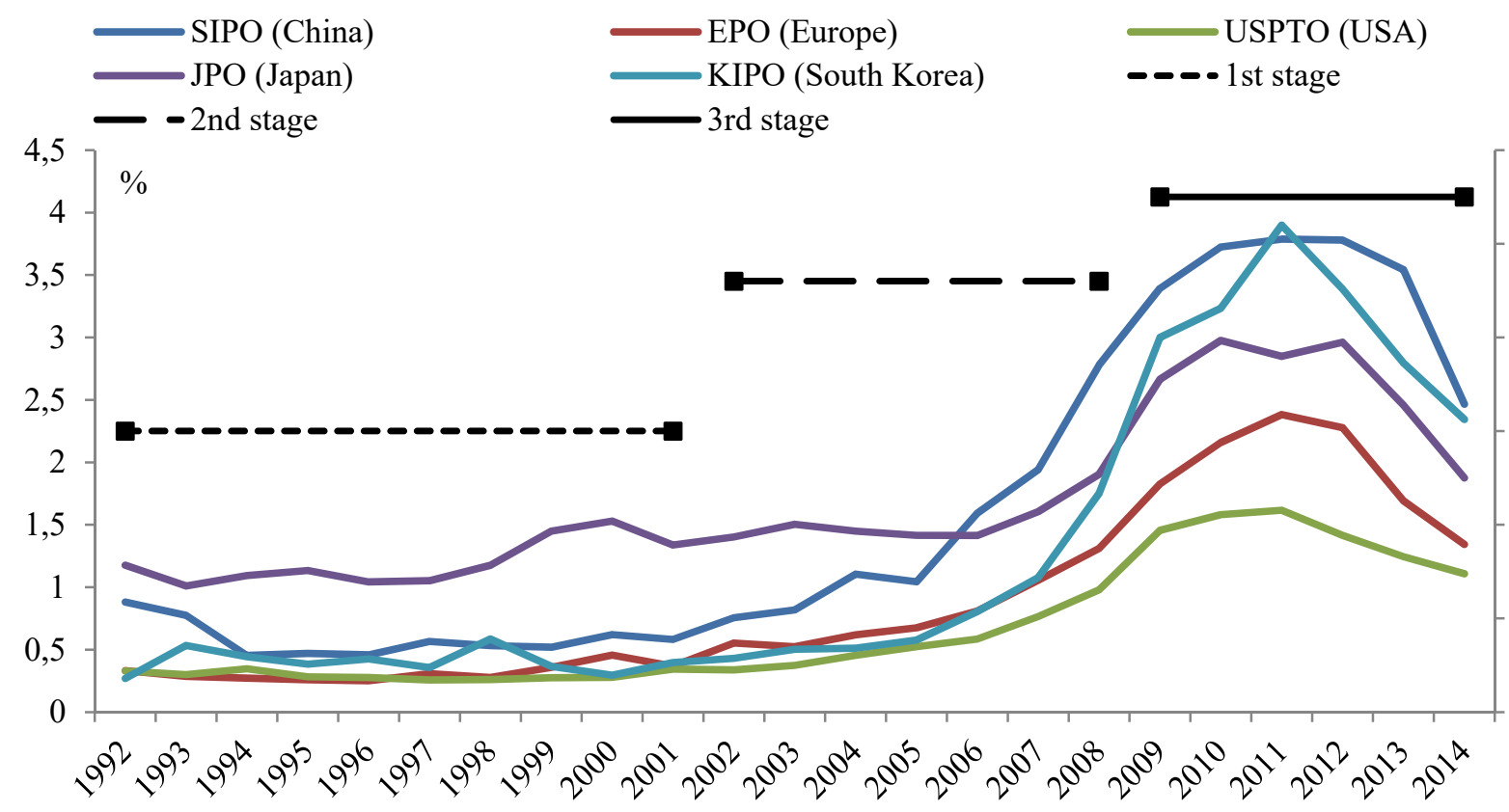

Source: Authors' calculation based on PATSTAT

The share of RETs in the total patents granted by the five offices are shown on the left axis of Figure 1. The share of RET patents in total patents granted by an IP office is not a measure of a country's inventive performance. It is an indicator of the dynamism of a geographical zone, both as a market for selling RETs and as an economy directing efforts towards their development. Several comments can be made regarding Figure 1. First of all, the dynamism of the Chinese, Korean and Japanese patent offices in comparison with the European and American offices, should be underlined. During the period analysed, RET patents generally have larger shares within the JPO, SIPO and KIPO, compared to the EPO and USPTO. This gap has been particularly marked since the 2000s. The JPO differs from its Asian neighbours in that the share of RET patents has historically been higher than in the other offices, although it did not experience the same acceleration during the 2000s. This difference is explained by the early high ambition of the policies implemented by the Japanese government to support the development of solar PV technology. The fact that the 1990s were a "lost decade" for the Japanese economy did not reduce the government's willingness to develop alternative energy 
technologies. As explained by Chowdhury et al. (2014), the two oil shocks drove the government to increase the share of RETs in the energy mix. The largest share of support was granted to solar PV technology through the New Sunshine Program and its expansion, and has allowed the solar PV sector to enjoy an abundant and stable budget for its development (Chowdhury et al., 2014). South Korea also started to develop new energy technologies in response to the two oil shocks. Nonetheless, the political support dedicated to RETs became more aggressively and strategically promoted in the early 2000s (Chen et al., 2014). At the end of 2008, the government chose to go further in the energy transition by releasing the "Low-Carbon Green Growth" plan that sets out South Korea's new national vision for the next fifty years. This plan explicitly targets the development of RETs as a means to foster economic growth and strengthen competitiveness.

In Figure 1, black lines represent three time periods that delimit three different stages of negotiations on low-carbon innovation. They are distinguished by the intensity of innovation and by the weights of countries in this global dynamic, with the gap between the so-called North and South countries gradually narrowing. They are detailed in the following sections. These three periods correspond both to different phases of international negotiations on lowcarbon technology and, as we can see in Figure 1, to innovation regimes of varying intensities. For this reason, the analysis of the dynamics of low-carbon innovation presented in this article will be structured around these three time periods.

\section{First stage: 1992-2001}

The issue of technology is central to international environmental negotiations. It was put forward as early as in 1972 with the adoption of 26 principles during the United Nations Conference on the Human Environment, or Stockholm Conference. The $20^{\text {th }}$ principle stipulated that "scientific research and development in the context of environmental problems, 
both national and international, must be promoted in all countries, especially the developing countries."

Negotiations on the more specific issue of climate technology, however, began later, in 1992, with the adoption of the United Nations Framework Convention on Climate Change (UNFCCC). The States Parties thus undertook to "promote and cooperate in the development, application and diffusion, including transfer, of technologies, practices and processes that control, reduce or prevent anthropogenic emissions of greenhouse gases" (UNFCCC, 1992, Article 4). These commitments would not be translated into concrete actions, particularly with regard to technology transfers, and a consultation phase would be conducted to study the modalities of technology transfer.

From the first COP held in Berlin in 1995 to COP4 in 1998, the Parties confined themselves to annual assessment of the commitments made in Article 4 of the UNFCCC (inventory of projects, construction of networks, definition of technologies). At COP4 in Buenos Aires, the decision was taken to initiate a consultation process, preparing a framework agreement on technology transfer for adoption. These consultations, particularly with developing countries, were to last until 2001. They resulted in the adoption and implementation at COP7 in Marrakech in 2001 of the Technology Transfer Framework (TTF). It endorsed five practices: (1) the publication of reports to identify and assess technological needs to reduce GHG emissions; (2) the creation and maintenance of a platform to facilitate the circulation of information on the implementation of the TTF; (3) the facilitation of technology transfer through the coordination of public policies and the removal of technical barriers; (4) the promotion of capacity-building for technology transfer; and (5) the creation of technology transfer mechanisms that entrust the Expert Group on Technology Transfer (EGTT) with the responsibility for facilitating the implementation of the agreement. 


\section{Second stage: $2002-2008$}

The EGTT was mainly responsible for clarifying the definition and modalities of technology transfer, a task ambitious if not doomed to failure. The international community had already failed a few years earlier in defining which transactions corresponded to technology transfer, without reaching a consensus. This failure was one of the reasons the negotiations conducted between 1976 and 1985 on the creation of an international code of conduct on international technology transfer were abandoned (for a historical review of technology transfer negotiations, see Sampath and Roffe, 2012). The EGTT did not address the most important question, namely how this technology transfer would be financed (Kline et al., 2004). This lack of concrete progress has contributed to increased tensions around the debate on technology transfer, which intensified ahead of the 2007 Bali conference (Shabalala, 2016). Industrial property rights on climate technologies have also been singled out by the Alliance of Small Island States for the potential barriers they create to the transfer of climate technologies.

During COP13 in Bali in 2007, the parties agreed to strengthen the technology transfer framework. It was seen as one of the pillars of a post-2012 climate agreement, the year in which the Kyoto Protocol would end. During the conference, the Poznan Strategic Programme on Technology Transfer was launched. It was formally adopted at COP14 in 2008 and allocated US\$50 million to finance technology needs assessments in developing countries and pilot projects (Glachant and Dechezleprêtre, 2017). This funding was managed by the Global Environment Fund (GEF), which is questionable insofar as it imposes a long period of assessment for funding requests, is not very responsive to new opportunities and has limited funding capacity (Chuffart-Finsterwald, 2014). 


\section{Third phase: 2009-...}

The end of the 2000s saw the debate on climate technology transfer intensify, highlighting the opposition between countries about industrial property rights, thus demonstrating the emergence of a geopolitics of low-carbon patents. In the run-up to the Copenhagen conference in 2009, Brazil, China, India, South Africa and the G77 insisted in their submissions in advance of the conference on the fear that industrial property rights would hinder the transfer of climate technology (Chuffart-Finsterwald, 2014). Developed countries opposed their request for partial relaxation of industrial property rules, before opposing any mention of patents in the text of the Agreement a year later (Correa, 2013). The defence of their strategic interests led the US and Europe to refuse the request made in 2012 by developing countries to assess the impact of industrial property rights on climate technology transfer. The choice was made not to mention industrial property in the final text or to recall the need for rules conferring strong protection upon patent holders to promote the development and diffusion of climate technologies (Chuffart-Finsterwald, 2014).

In practice, the negotiations would succeed only in strengthening existing mechanisms without making any real progress in technology transfer. A further step was taken with the creation at COP16 (Cancun) in 2010 of the "Technology mechanism" which ended the mandate of the EGTT and entrusted two entities, the Technology Executive Committee (TEC) and the Climate Technology Centre and Network (CTCN), with remits to assess countries' technological needs, formulate public policy recommendations and create and expand a network of low-carbon technology actors. However, these two entities were given limited power. The TEC is made up of about twenty experts and its main activity is to draft proposals to States at each new COP aimed at accelerating technology transfer. The CTCN has limited capacity with a budget of $\$ 14$ million in 2015 (Glachant and Dechezleprêtre, 2017). After 
implementation, the "Technology mechanism" was strengthened at COP21 in Paris. Although the Paris Agreement is often presented as a success and a major step forward in international climate negotiations, the position on technology transfer has remained the same. The Parties contented themselves with reaffirming their shared "long-term vision on the importance of fully realizing technology development and transfer" (Article 10 of the Paris Agreement).

Geo-economic tensions around international negotiations on low-carbon technology increased over the three periods detailed. In parallel with international negotiations, governments implemented their own RET strategies supporting the development of these technologies more or less ambitiously, with varying results. In this context, patent data reveal the efforts made by the negotiating parties and the results achieved. More precisely, we are interested in three dimensions of the innovation dynamics in RETs. First, we will look at the efforts made by the main actors in low-carbon innovation to specialize in two core technologies of the energy transition: solar PV and wind power. Second, we will assess the extent to which these efforts have or have not enabled these countries to produce better RET inventions. Finally, because patents allow some form of control over technology, we will be able to compare the extent and nature of the geographical scope of their control over RETs across countries.

\section{Measuring countries' efforts to foster low-carbon innovation}

\section{Methodology: the normalized Revealed Technical Advantages index}

Sorting RET patents by nationality allows us to analyse the specialization of the main innovative countries in two major technologies: (1) onshore and offshore wind and (2) solar photovoltaic. A widely used indicator in the literature to measure a country's relative degree of specialization in a technological field is the Revealed Technical Advantage (RTA), 
originally proposed in an article by Soete (1987). This indicator is defined as the ratio between the share of the total number of inventions produced by a country globally in a particular technology and the worldwide share of inventions produced by the country in all technologies. It is particularly useful for international comparisons because the propensity to patent can vary from one country to another, regardless of innovation performance. Finally, we normalize the RTA indexes so that the same weight is given to negative and positive changes (Thoma, 2013). Although RTA indexes are effective in quantifying a country's relative specialization in a technology sector, they have two limitations identified by Cantwell and Jeanne (1999). First, the construction of these indexes for countries producing few inventions creates potentially large variations in the index from one period to another and makes comparison with other countries more difficult. Second, the calculation of RTAs for small countries often suggests they are highly specialized as their limited resources force them to focus on a small number of technology sectors (this criticism applies mainly to Denmark among the countries we analyse). A strictly positive normalized RTA index indicates a relative specialization of the country in the sense that it produces a larger share of inventions in this technological sector than in all sectors, whereas a strictly negative index indicates a relative lack of specialization in the sector.

Normalized RTA indexes are computed for each of the three stages of climate negotiations presented in the previous section.

\section{Renewable energy innovation: historical innovators and newcomers}

RTA indexes summarize two dimensions of a country's relative technological specialization. First, they reflect its share in the production of inventions belonging to a particular technology and thus capture its specialization in relation to other countries. Second, by relating this share to the country's share in the production of inventions, all technologies taken together, RTA indexes express specialization in a technology relative to the overall performance of the 
country in all innovation sectors. These indexes therefore help track to what extent a technology may or may not be a priority for a country's innovation sectors. The indexes, in their standardized form, are shown for wind in Figure 2 and for solar PV in Figure 3.

Figure 2: Evolution of normalized RTA indexes in wind power technology

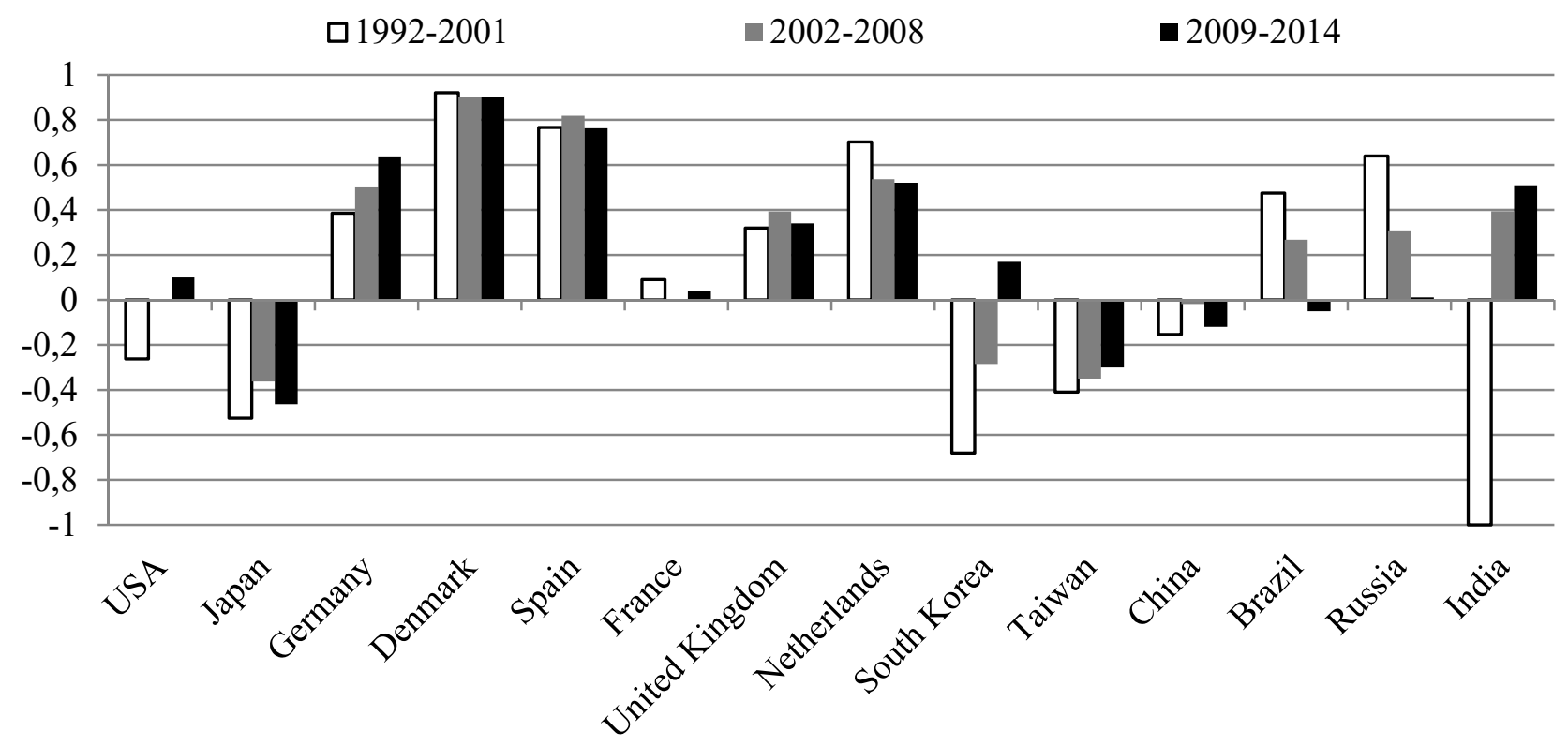

Source: Authors' calculation based on PATSTAT

Figure 2 accurately reflects the commitment of several European countries to the development of wind technology. There is a high degree of specialization, particularly in Germany, Denmark and Spain. These three countries have been pioneers in Europe in the development of this technology, in terms of both innovation and deployment. In 2000, they accounted for $85 \%$ of newly installed wind power capacity in Europe. The deployment of wind power would then accelerate in the other European countries to represent $68 \%$ of new installations in Europe in 2012 (EWEA, 2012). The three countries nevertheless succeeded in developing a first-mover advantage, first creating a dynamic domestic market for their companies and then exporting their technologies to their European neighbours (Baudry and Bonnet, 2019). In 
$2008,94 \%$ of the cumulative installed wind power capacity in Italy and $93 \%$ in Portugal used technologies produced by seven German, Danish and Spanish companies (ibid.). The United Kingdom and the Netherlands have also built up a strong and constant specialization in wind technology over time. This is the result of early R\&D investments in wind technology in these countries. Total cumulative UK R\&D expenditure on wind technology between 2000 and 2012 amounted to $€ 307$ million, an amount comparable to that of Denmark over the same period ( $€ 309$ million). The Netherlands also committed $€ 195$ million between 2000 and 2016 to $R \& D$ for wind technology, competing with Spain, which spent $€ 195$ million during the same period. France does not appear to be a specialist in this technology, as the country has been more cautious in supporting the sector, as shown by the low level of cumulative R\&D investment in the technology between 2000 and 2016, which amounted to $€ 68$ million.

Japan and the USA, two major innovative countries, share the common characteristic of being under-specialized in wind technology compared to the rest of the world and to their share in innovation sectors, all technologies taken together. Japan's specialization has gradually faded. The USA, on the other hand, stepped up its efforts in the wind energy sector over the three time periods analysed. Nevertheless, it remains relatively under-specialized in wind technology. This is due to the particularity of the US R\&D strategy. The country spent $€ 990$ million on R\&D for wind technology between 2000 and 2016. These resources were however directed very early-on towards the development of multi-megawatt turbines and allocated directly to the aerospace industry, two factors that explain the lower efficiency of government financing (Lewis and Wiser, 2007).

South Korea and India have interesting profiles since they have become highly specialized in wind technology over only a few decades, demonstrating the efforts made by the public 
authorities to develop domestic industries. In particular, India has succeeded in creating a national champion, Suzlon, which succeeded in becoming the sixth-largest wind turbine producer in the world in 2014. However, the firm's future is uncertain since it has recently suffered several failures and its financial situation has deteriorated. ${ }^{8}$ The profiles of Brazil and Russia indicate that these two countries have not engaged in the wind energy sector. Although they were initially relatively specialized in the technology, neither country was able to keep up with the pace of innovation deployed by other countries and each gradually lost its relative specialization. Finally, China has maintained a relatively stable degree of relative specialization in the wind energy sector. While the growth of the wind energy sector in China is generally associated with the implementation of the Renewable Energy Law in 2005 (REL 2005), which involves an ambitious policy of demand-driven support, the country was already pursuing the objective of developing this sector before REL 2005. In 1996, China was the country that produced the most wind turbines worldwide (World Bank, 2006). Because of its good wind resources, particularly in Inner Mongolia, China began a rural electrification programme in the 1970s based on the use of wind energy, as well as other renewable energy sources (Lew, 2000). In parallel, central and local governments implemented a set of measures at the end of the 1950s to support the development of a domestic wind energy sector. However, China does not have any relative specialization since its share in the totality of wind power inventions produced worldwide is almost equal to that in the totality of inventions produced, all technologies combined.

\footnotetext{
${ }^{8}$ https://www.livemint.com/Money/Rwtli1bRZ6jHh1Q2JVXtiI/Four-years-since-Senvion-sale-turnaroundcontinues-to-elude.html
} 
Figure 3: Evolution of normalized RTA indexes in solar PV technology

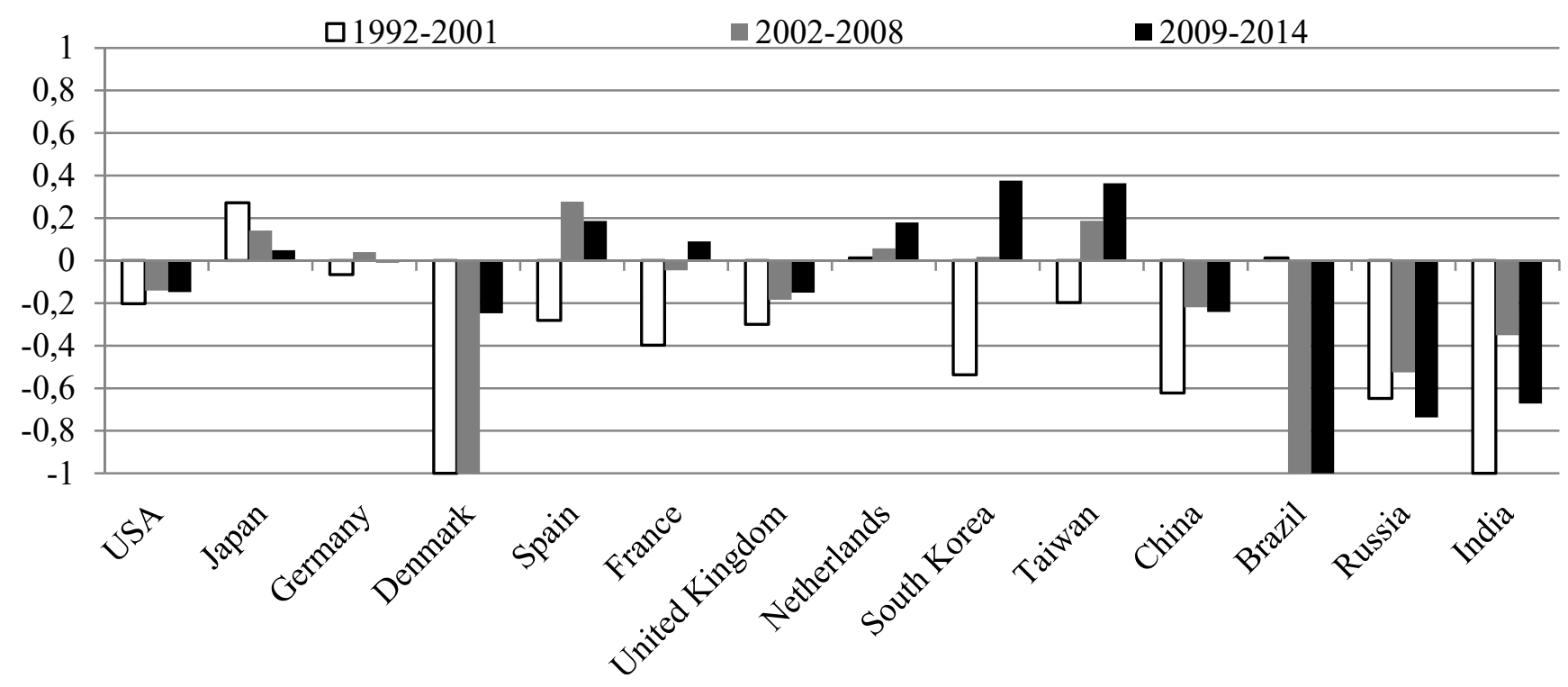

Source: Authors' calculation based on PATSTAT

The case of solar PV technology is different in the sense that fewer countries have a relative specialization. In Europe, the countries analysed show a low degree at best of relative specialization, as in the case of Spain, France and the Netherlands during the period 20092014.

The two most important countries to focus on in order to capture the dynamics of innovation in the solar PV sector are most likely South Korea and Taiwan. Both succeeded between 1992 and 2014 in developing strong relative specialization in it. This is explained by the specialization that they had developed upstream in the semiconductor sector, which is intrinsically linked to solar PV technology (Wu, 2014). Moreover, Taiwan has favoured the development of crystalline silicon cells while Korean innovators have focused on improving new generations of solar photovoltaic technologies (ibid.). The development of the two countries' solar PV expertise has helped accelerate the global pace of innovation, explaining Japan's loss of relative specialization. Among the countries studied, Japan is the country that was most highly specialized in solar PV during the period 1992-2001. Its relative 
specialization has declined over time, yet Japan has continued to innovate in the technology, but at a slower pace than new entrants to the sector.

These results reflect the specialization dynamics of countries in two central technologies of the energy transition. They thus show how national innovation systems allocate their resources and position themselves relative to the rest of the world. However, they say nothing about the performance of these innovation systems, which is linked to the value of inventions produced by countries. This is discussed in the following section.

\section{Measuring countries' innovation performance in renewable energy technologies and their geographical influence}

\section{Methodology: how to measure the value of patented inventions}

Measuring the value of patented inventions is both difficult and necessary. The economic literature highlighted very early on the fact that the value of patented inventions follows a highly asymmetric distribution and is skewed towards high levels of invention value (see, for example, Griliches, 1990). As an illustration of this heterogeneity in the value of inventions, we can cite the study by Scherer and Harhoff (2000), which, based on a survey of inventors, estimates that $54 \%$ of the total value of the 772 inventions contained in the sample is concentrated in only 5 inventions. There are many methods for measuring the value of inventions (for a review of existing approaches, see Squicciarini et al., 2013). Here, we focus on high-value inventions and propose a new index of the value of inventions. One index often used to count only high-value inventions is the triadic inventions count. These are the families of patents that protect inventions at least in the US Office (USPTO), Japanese Office (JPO) and European Office (EPO) - the three main global patent offices. The advantage of counting triadic families is that they reduce the influence of geographical location and thus facilitate international comparisons (OECD, 2009). More recently, particularly because of the role 
played by China and South Korea in global innovation dynamics, researchers have proposed that we no longer focus solely on triadic inventions but also on those patented at the SIPO and KIPO (Dernis et al., 2015). In this section, the assessment of country performance is measured by counting the number of inventions patented at these five offices, namely the IP5 inventions, weighted by the number of claims granted by the EPO to the patent protecting the invention there. The PATSTAT database has a very high level of detail that can be used to determine the number of claims associated with each patent granted by the EPO. The claims of a patent delimit the boundaries of the exclusivity rights the patent holder holds. The number of claims is therefore a reflection of the breadth of the patent (OECD, 2009). Because granting a patent that is too broad generates a cost for society, examiners seek to grant only the number of claims strictly necessary, making claim data very valuable for the assessment of protected inventions. Indeed, the number of claims that are granted by the examiner reflects the well-known trade-off associated with a patent system (see Nordhaus, 1969 and 1972). A too strong patent will generate a dead weight loss due to the monopoly position over the invention. A too weak patent will reduce the incentives to apply for a patent. In this case inventors will not innovate, or they will prefer to maintain the industrial secret on the invention; reducing the access of society to knowledge. To this extent, the number of claims capture the results of the examination of the patent application; a high number of claims in a patent document corresponds to a high value invention because the examiners will concede a high market power in exchange of the expected long term benefit society will earn from the invention. Finally, the EPO outperforms the USPTO and JPO in terms of examination process quality (Van Pottelsberghe de la Potterie, 2011), making claims from the EPO more useful in assessing the value of inventions. 


\section{The technological leaders in the renewable energy technologies}

In Figure 4, we represent for both the 2002-2008 and the 2009-2012 periods the count of IP5 inventions produced by the most innovative countries in RETs, all technologies taken together, weighted by the claims associated with each invention by the EPO. The choice is made to emphasize the 2002-2008 and 2009-2012 periods as the number of patents delivered to RE inventions by the main patent offices has significantly grew after 2002 , as can be seen on Figure 1. On the right axis of Figure 4, we also report the average number of claims associated with the inventions produced by each country. This information helps account for differences between countries in terms of average invention value.

Figure 4: Count of IP5 patent families in RET sectors, weighted by EPO claims (left axis) and average number of EPO claims per invention (right axis)

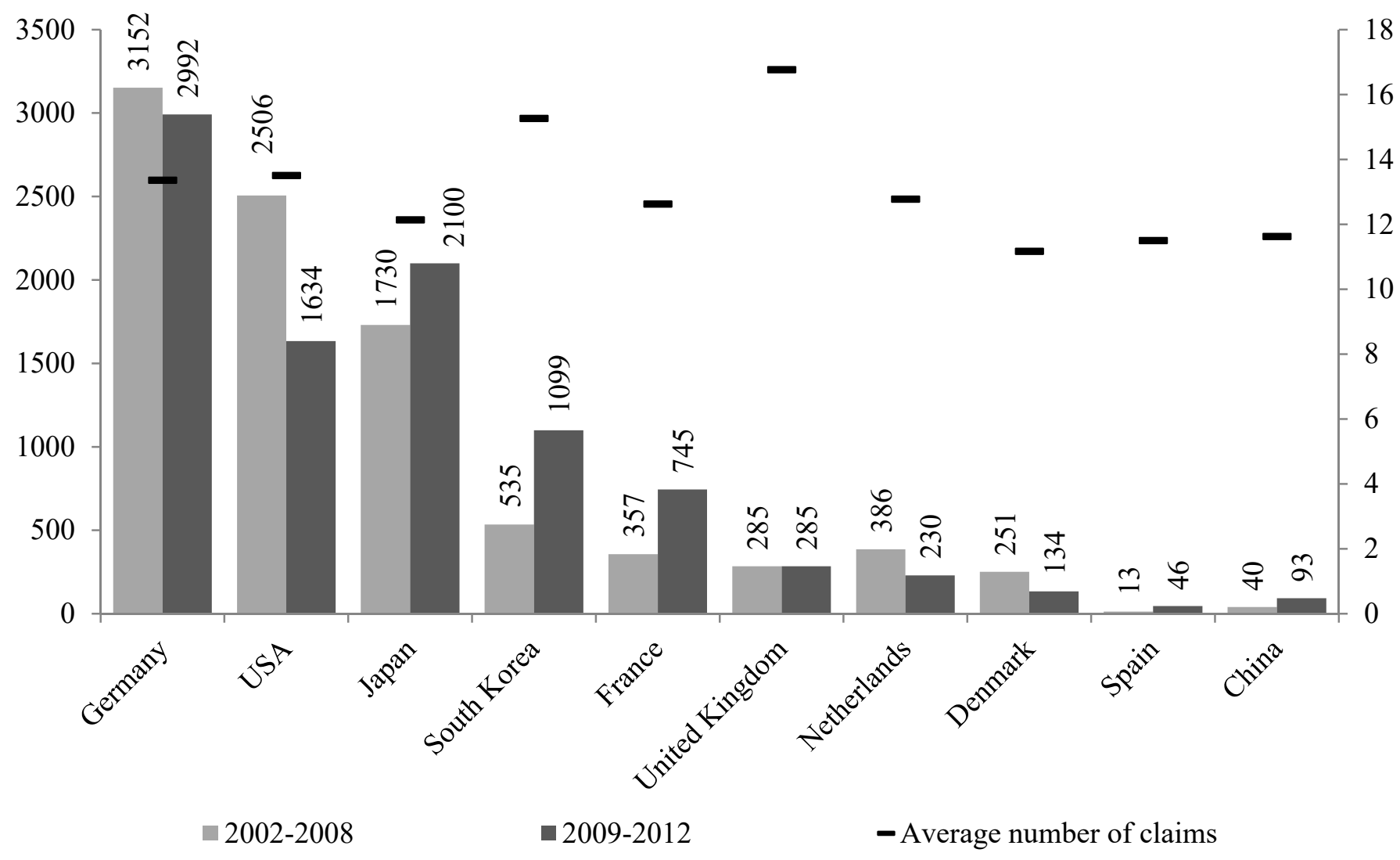


Figure 4 shows Germany's technological leadership in RETs. From one period to the next, the country's performance remained relatively stable as it accounted for $29 \%$ of IP5 inventions produced worldwide between 2002 and 2008, weighted by claims. This share fell to $28 \%$ for the period 2009-2012. This situation contrasts with that of the United States, the share of which in global production of high-value inventions fell; it is the only country for which such a deterioration in innovation performance can be observed. The situation in Japan is particularly interesting because its performance has strengthened from one period to the next. As showed in Figure 4, Japan's performance increased by $21 \%$ between the two periods. Despite declining specialization in solar PV, the country maintained a production of high value inventions. It has also developed its innovative capacities in the fuel-from-waste sector, in which it produces many inventions compared, for instance, with the United States.

South Korea and France stand out as the two countries that managed to significantly improve their innovation performance over the $2009-2012$ period. For France, this is partly due to a catch-up phenomenon, the country having a solid technological base but long neglecting renewable energy technologies, as shown by the analysis of its specialization in PV solar and wind energy developed earlier. South Korea's good innovation performance indicates that the change of direction initiated in 2008 via the "Low-Carbon Green Growth" strategy was saw an increase in innovation as well as better performance in the production of high-value inventions. It can also be noted that Korean inventions are on average protected by a higher number of claims than those of Germany, the USA, Japan or France, suggesting greater average value. We conclude that while China has strengthened its innovation performance 
from one period to the next, it lags behind most European countries and remains significantly behind the trio of Germany, Japan and the USA.

\section{Methodology: measuring the geographical scope of low-carbon innovation with patent families}

As we explained at the beginning of the previous subsection, the same invention is protected first by a priority patent and then, if necessary, by a family of patents granted by different patent offices. ${ }^{9}$ Analysing how inventions that are produced by a country are then patented abroad helps identify the foreign markets of interest for the country in question and its firms. In order to analyse the geographical scope of RET protection, we focus on the five countries that have reached the best innovation performance in these technologies, as measured in the previous section, plus China, which has produced a large number of inventions in RETs. For each country, we analyse how the legal protection over its inventions is extended towards foreign countries. To do so, we extract from the PATSTAT database all RET inventions produced by each country during the 2002-2008 and the 2009-2012 periods. We examine how these inventions are patented abroad and compute the shares of patents in the recipient countries.

\section{Towards market segmentation in renewable energy innovation?}

In the six graphs in Figure 5, the geographical distribution of industrial property rights granted by foreign countries on inventions produced by each of the six countries can be observed. For each period, we represent the main recipient countries and the rest of the world separately. For both periods we give the Herfindahl-Hirschman Index (HHI) computed as the sum of the squares of the share of each recipient country. This helps compare the degree of concentration

\footnotetext{
${ }^{9}$ The patent family refers to the patents granted by different offices around the world to protect the same invention.
} 
of the recipient countries between the different producing countries and measure the evolution of this concentration between the two periods.

\section{Figure 5: Distribution of the geographical scope of RET industrial property rights}

USA - HHI 2002-2008 : 1217 ; HHI 2009-2012 : 1624

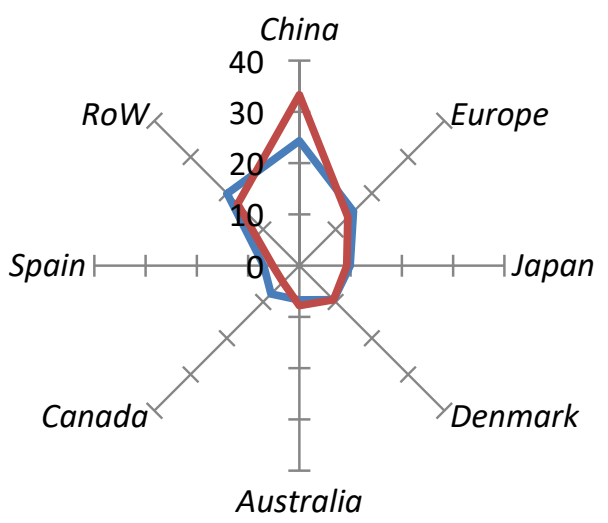

Japan - HHI 2002-2008 : 2038 ; HHI 2009-2012 : 2243

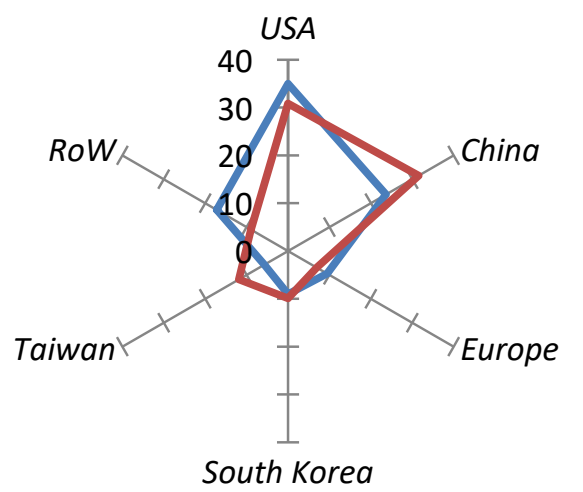

Germany - HHI 2002-2008: 1070 ; HHI 2009-2012 : 1255

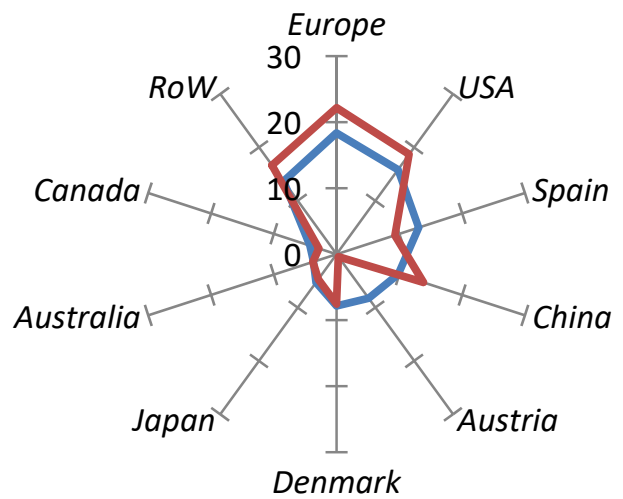

France - HHI 2002-2008 : 978 ; HHI 2009-2012: 1282

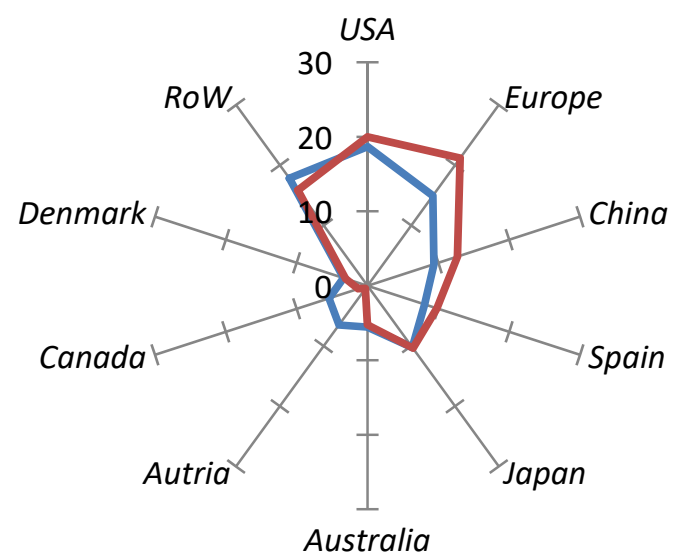

China - HHI 2002-2008: 1919 ; HHI 2009-2012 : 1907

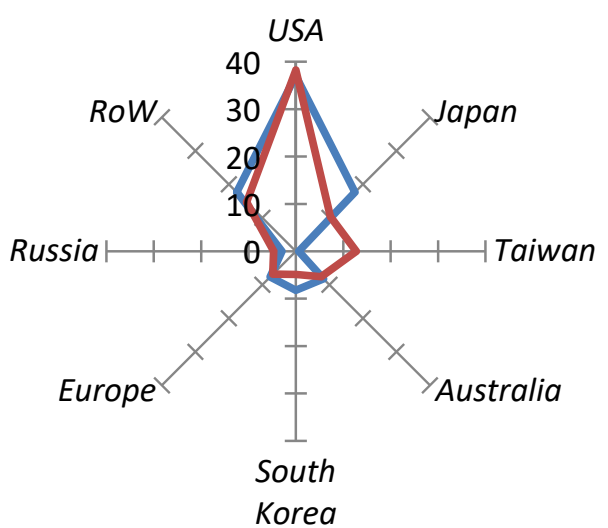

South Korea - HHI 2002-2008 : 2585 ; HHI 2009-2012:

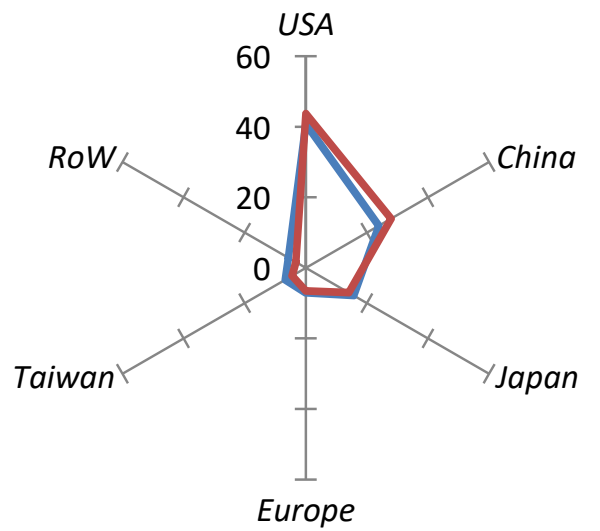

200

200 
Figure 5 calls for three comments that we consider highly important in the context of this research. They concern: (i) the relationship between the United States and China, (ii) the situation in Europe and (iii) the South Korean strategy.

First, it appears from these graphs that the USA and China have a specific relationship. The United States has been the preferred destination of China to protect its inventions. The way Chinese firms protect their inventions abroad has remained stable from one period to the next, as shown by the relative stability of the shape of the radar shown in Figure 5 for China. The only observable change from one period to another is that, during the period 2002-2008, Chinese companies filed more patents in Japan, and that Japan's share in the countries receiving Chinese patent applications has decreased while Taiwan's increased during the period 2009-2012. That said, China's geographical targets in terms of industrial property demand are highly concentrated from one period to the next and the USA remains the focus: $37 \%$ of patents obtained for Chinese inventions in RETs between 2002 and 2009 were granted in the USA, rising to $38 \%$ during the $2009-2012$ period. From the US perspective, it seems that China's importance has grown from one period to the next. The country has become an important market for RETs and has also developed its own supply chains in these technologies, which explains the willingness of US firms to protect themselves from imitation. Between 2009 and 2012, patents granted by China to US inventions represented $33.4 \%$ of the total number of patents obtained abroad for US inventions in RET sectors. From one period to the next, China became more important from the US point of view as regards the protection of RETs. This is illustrated by the increase in the HHI index of the geographical concentration of foreign patent filings on RETs of US origin: at 1217 during the period 2002- 
2008, it reached 1624 for the period 2009-2012. This increase is attributable to China's greater importance.

Europe appears to be a region where the situation has remained fairly stable from one period to the next. Moreover, while it represents an important market for RETs, it is not a preferred target for foreign countries to protect their inventions. During the period 2009-2012, the USA, Japan, China and South Korea patented $13.4 \%, 7 \%, 6.9 \%$ and $6.5 \%$ respectively of their domestic inventions in RETs at the EPO. This is due to the performance of European countries in RET sectors, led by Germany, France and the United Kingdom, which are countries with a high capacity of innovation, as well as the Netherlands, Denmark and Spain, which have developed significant relative advantages in RETs. The European market is therefore a relevant target for European countries, as evidenced by the fact that for Germany and France, the filing of patents on RETs at the EPO has become an increasingly important strategy from one period to the next. During the period 2002-2008, the geographical area favoured by French innovators to protect their inventions in RETs was the USA, as $18.7 \%$ of patents obtained abroad were American. During the same period, $15 \%$ of patents obtained abroad for French inventions were obtained from the EPO. This share increased in 2009-2012 to $20 \%$, while the share of foreign patents obtained from the USA increased by only 1 point. Germany is the country that during the period 2009-2012 had the lowest geographical concentration in its foreign patent applications. From one period to the next, the country has favoured patents from the EPO, the USA and also China, which has become an important target since $14 \%$ of foreign patents on German inventions were granted by the Chinese patents office during the 2009-2012 period. 
Finally, the South Korean strategy is worth analysing since, as we have seen, it has succeeded in both strengthening its specialization in RETs and improving its innovation performance over time. However, its strategy of acquiring patents abroad on its inventions in RETs remained unchanged between 2002-2008 and 2009-2012. South Korea focuses on three countries: the USA, China and Japan. Europe, for example, is not a very popular area among South Korean innovators. This is due to the performance of some European countries in RETs, which may reduce the incentive to enter the European market as they would be too dangerous as competitors. In addition, South Korea's greater geographical proximity to China, the USA and Japan makes it more attractive to obtain patents in these countries in order to supply their markets. Moreover, the penetration of the US market to sell Korean technologies is a strategic imperative for the Korean economy. This strategy was accompanied by the creation of a sovereign patent fund, Intellectual Discovery, aimed at reducing Korea's balance of technology payments deficit, acquiring key technologies in the IT sector for the benefit of Korean firms, and facilitating access to the US market. The fund thus buys patents to grant licenses at preferential prices to Korean companies. The acquisition of US patents protects against legal attacks and allows for market penetration. Approximately $82 \%$ of the fund's assets in 2016 were patents granted by the USA. ${ }^{10}$

\section{Conclusion}

The diffusion and improvement of RETs are crucial for the energy transition. Intellectual property rules shape the production and diffusion of innovation and there are two opposing discourses about their effects in the context of climate negotiations. For developed countries, the existence of intellectual property rules is a necessary condition for the diffusion of new technologies that innovators would keep secret in the absence of protection. For developing

\footnotetext{
${ }^{10}$ https://www.iam-media.com/defensive-aggregation/new-priorities-and-strategies-sovereign-patent-funds
} 
countries, intellectual property allows the exercise of monopoly power that, by increasing the price of new technologies, hinders access to them. This opposition is exacerbated in the case of RETs since innovation in these sectors is highly dependent on government intervention (implementation of climate policies, financing of innovation, historical share in the energy sectors) and overlaps with energy security issues. These different elements help understand the technology-related geo-economic tensions that drive international climate negotiations. We have stressed that low-carbon innovation and international climate negotiations are unique in that they are co-evolving. On the one hand, the countries with the best technological assets in RETs will perceive the adoption by other countries of GHG mitigation commitments as an opportunity to gain market share. On the other hand, countries lagging behind on these technologies will see the adoption of such commitments as a threat to their economies and energy security if they are not accompanied by technology transfer agreements. In this context, patent data can be used to produce an overview of RET innovation and assess which countries are leaders in low-carbon innovation and to what extent the situation has changed over time. Low-carbon innovation is concentrated in the hands of only a few countries and the dynamics of low-carbon innovation in the five largest patent offices show that a strong acceleration took place during the 2000 s.

Analysis of how countries specialize in wind power and solar PV technologies suggests that national strategies foreshadow a new organization of the innovation process in new energy technologies. Unsurprisingly, a few European countries stand out, having developed a very strong specialization in wind technology, which is particularly true of Spain, Denmark and Germany. Conversely, although Japan and the USA are major innovators, their efforts to develop this technology are weaker, compared to the efforts they make in other technological fields and those made by other countries. Nonetheless, Europe has not yet won the innovation 
race in the wind power sector as newcomers such as India and South Korea have made major efforts to specialize in the technology. Regarding the solar PV sector, lower specialization degrees were observed on average. Between 2009 and 2014, South Korea and Taiwan nonetheless made considerable efforts to specialize in it and seem to stand out from other countries.

The assessment of countries' innovation performance provides a more conservative picture in the sense that three countries tend to prove their technological superiority in RETs, namely Germany, the USA and Japan. The first clearly dominates innovation in RETs at the European level and it should be noted that a degradation of the US performance is observed during the 2009-2014 period, in comparison with 2002-2008. Two countries have managed to significantly improve their performance over the years: France and South Korea. China, meanwhile, lags behind in terms of innovation performance. Although the country patents a lot of inventions domestically, few are patented in the other top patent offices. These results about innovation performance are supplemented by the analysis of the geographical scope of intellectual property on RETs. As such, we consider how each country seeks protection abroad and where.

This highlights three results. First, the USA and China have a special relationship in that they are each other's priority targets for acquiring industrial property rights in RETs. In the current context of the trade war between the two countries, particularly because of US suspicions with regard to China over non-compliance with industrial property rules, this result confirms the idea that the acquisition of patents granted by the other country is strategic. Secondly, it appears that Europe is not a priority area for other countries and that European countries favour the acquisition of industrial property rights within the European area. Balanced against 
the strong performance of several European countries, Europe appears a more autonomous region in the sense that it is its own main market, which is supplied mainly by European RETs. Finally, South Korea's strategy of specialization and performance improvements in RETs has been accompanied by relative stability in its targets. Between 2002 and 2012, Korean inventors continued to favour the acquisition of patents to protect their inventions from US, Japanese and Chinese offices. The USA in particular is a key target for the Korean economy, in both the field of RETs and other sectors as illustrated by sovereign patent funds.

Innovation in RETs has become a global challenge in recent decades. No geographical area seems to have escaped the acceleration of industrial property rights acquisition on new technologies in renewable energy sectors, reflecting the anticipation among various players that they will become key assets in the future. As countries engage in the energy transition and some accumulate RET industrial property rights, geopolitical tensions over low-carbon technology will increase. In this context, in-depth analysis of the Chinese strategy seems to us to be a promising research area insofar as the country is the leading installer of renewable electricity capacity and produces many Chinese patents in these fields, yet still seems relatively behind in terms of technology compared to the leading countries.

\section{REFERENCES}

Abdel-Latif, A. (2015). Intellectual property rights and the transfer of climate change technologies: issues, challenges, and way forward. Climate Policy, 15(1), 103-126.

Barton, J. H. (2007). Intellectual property and access to clean energy technologies in developing countries. ICTSD Issue Paper, 2. 
Baudry, M., \& Bonnet, C. (2019). Demand-pull instruments and the development of wind power in Europe: a counterfactual analysis. Environmental and Resource Economics, 73(2), 385-429.

Bodansky, D. (2016). The Paris climate change agreement: a new hope?. American Journal of International Law, 110(2), pp. 288-319.

Cantwell, J., Janne, O., (1999). Technological globalization and innovative centres: the role of corporate technological leadership and locational hierarchy. Research Policy, Vol. 28, pp. 119-144.

Chen, W. M., Kim, H., \& Yamaguchi, H. (2014). Renewable energy in eastern Asia: Renewable energy policy review and comparative SWOT analysis for promoting renewable energy in Japan, South Korea, and Taiwan. Energy Policy, 74, pp. 319-329.

Chowdhury, S., Sumita, U., Islam, A., \& Bedja, I. (2014). Importance of policy for energy system transformation: Diffusion of PV technology in Japan and Germany. Energy policy, 68, pp. 285-293.

Chuffart-Finsterwald, S. (2014). Environmental technology transfer and dissemination under the UNFCCC: Achievements and new perspectives. Environmental claims journal, 26(3), 238-260.

Correa, C. M. (2013). Innovation and technology transfer of environmentally sound technologies: the need to engage in a substantive debate. Review of European, Comparative \& International Environmental Law, 22(1), 54-61.

Criekemans, D., (2018). Geopolitics of Renewable Energy Game and Its Potential Impact upon Global Power Relations. The Geopolitics of Renewables. Scholten, Daniel (Ed.), pp. $37-$ 73.

Dechezleprêtre, A., Glachant, M., \& Ménière, Y. (2013). What drives the international transfer of climate change mitigation technologies? Empirical evidence from patent data. Environmental and Resource Economics, 54(2), 161-178. 
Dernis H., Dosso M., Hervás F., Millot V., Squicciarini M. and Vezzani A. (2015). World Corporate Top R\&D Investors: Innovation and IP bundles. A JRC and OECD common report. Luxembourg: Publications Office of the European Union.

Dussaux, D., Dechezlepretre, A., \& Glachant, M. (2018). Intellectual property rights and the transfer of low-carbon technologies to other countries. LSE Business Review.

EWEA, F., \& Moccia, J. (2013). Wind in Power 2012 European statistics.

Fuss, S., Canadell, J. G., Peters, G. P., Tavoni, M., Andrew, R. M., Ciais, P., ... \& Le Quéré, C. (2014). Betting on negative emissions. Nature Climate Change, 4(10), pp. 850.

Glachant, M., Dechezleprêtre, A., (2017). What role of climate negotiations on technology transfer? Climate Policy, Vol. 17, n8, pp. 962-981.

Griliches, Z. (1990). Patent Statistics as Economic Indicators: A Survey. part 1-2 (No. 3301). National Bureau of Economic Research.

Iyer, G., Hultman, N., Eom, J., McJeon, H., Patel, P., \& Clarke, L. (2015). Diffusion of lowcarbon technologies and the feasibility of long-term climate targets. Technological Forecasting and Social Change, 90, pp. 103-118.

Kline, D., Vimmerstedt, L., \& Benioff, R. (2004). Clean energy technology transfer: A review of programs under the UNFCCC. Mitigation and Adaptation Strategies for Global Change, 9(1), 1-35.

Larkin, A., Kuriakose, J., Sharmina, M., Anderson, K. (2018). What if negative emission technologies fail at scale? Implications of the Paris Agreement for big emitting nations. Climate Policy, 18(6), pp. 690-714.

Lew, D. J. (2000). Alternatives to coal and candles: wind power in China. Energy Policy, 28(4), 271-286.

Lewis, J. I., \& Wiser, R. H. (2007). Fostering a renewable energy technology industry: An international comparison of wind industry policy support mechanisms. Energy policy, 35(3), 1844-1857. 
Meilstrup, P. (2010). The runaway summit: the background story of the Danish presidency of COP15, the UN Climate Change Conference. Danish foreign policy yearbook 2010, pp. 113135 .

Nordhaus, W. (1969) Invention, Growth and Welfare. Cambridge, Mass.: MIT Press.

Nordhaus, W. (1972) The optimal life of the patent: reply. American Economic Review, 62, $428-431$.

Ockwell, D. G., Haum, R., Mallett, A., \& Watson, J. (2010). Intellectual property rights and low carbon technology transfer: Conflicting discourses of diffusion and development. Global Environmental Change, 20(4), 729-738.

OECD. (2009). OECD Patent Statistics Manual. OECD (Ed), Paris.

Peters, G. P., Andrew, R. M., Canadell, J. G., Fuss, S., Jackson, R. B., Korsbakken, J. I., ... \& Nakicenovic, N. (2017). Key indicators to track current progress and future ambition of the Paris Agreement. Nature Climate Change, 7(2), pp. 118.

Rogelj, J., Meinshausen, M., \& Knutti, R. (2012). Global warming under old and new scenarios using IPCC climate sensitivity range estimates. Nature climate change, 2(4), pp. 248.

Rose, S. K., Richels, R., Blanford, G., \& Rutherford, T. (2017). The Paris Agreement and next steps in limiting global warming. Climatic Change, 142(1-2), 255-270.

Sampath, P., \& Roffe, P. (2012). Unpacking the international technology transfer debate: fifty years and beyond. ICTSD, Issue Paper, 36.

Scherer, F. M., \& Harhoff, D. (2000). Technology policy for a world of skew-distributed outcomes. Research policy, 29(4-5), 559-566.

Shabalala, D. (2016). Intellectual property, climate change and development. The WIPO Journal, 8(1).

Soete, L., (1987). The impact of technological innovation on international trade patters: The evidence reconsidered. Research Policy, Vol. 16, pp. 101-130. 
Squicciarini, M., Dernis, H., \& Criscuolo, C. (2013). Measuring patent quality.

Stern, N., Peters, S., Bakhshi, V., Bowen, A., Cameron, C., Catovsky, S., ... \& Edmonson, N. (2006). Stern Review: The economics of climate change (Vol. 30, p. 2006). London: HM treasury.

Thoma, G., (2013). Quality and Value of Chinese Patenting: An International Perspective. Seoul Journal of Economics, Vol. 26, no. 1, pp. 33-71.

United Nations., United Nations., \& Canada. (1992). United Nations Framework Convention on Climate Change. New York: United Nations, General Assembly.

Van Pottelsberghe de la Potterie, B. (2011). The quality factor in patent systems. Industrial and Corporate Change, 20(6), 1755-1793.

Verdolini, E., \& Bosetti, V. (2017). Environmental policy and the international diffusion of cleaner energy technologies. Environmental and resource economics, 66(3), 497-536.

World Bank, (1996). China: Renewable energy for electric power, 15592-CHA, World Bank, Washington, DC, 11 September.

$\mathrm{Wu}, \mathrm{C} .,(2014)$. Comparisons of technological innovation capabilities in the solar photovoltaic industries of Taiwan, China, and Korea. Scientometrics, Vol. 98, pp. 429-446. 